\title{
Earliest Jurassic (Hettangian) psiloceratoid ammonites from a subrosion pipe at Winterswijk, the eastern Netherlands
}

\author{
A.A. Klompmaker ${ }^{1, *}$ \& B.J.H.M. van den Berkmortel ${ }^{2}$ \\ 1 Morelissenstraat 9, 8095 PX 't Loo Oldebroek, the Netherlands. \\ 2 Schelde 56, $5751 \mathrm{VH}$ Deurne, the Netherlands. \\ * Corresponding author. Email: adielklompmaker@gmail.com
}

Manuscript received: June 2007; accepted: November 2007

\begin{abstract}
A small faunule of fragmentary Hettangian (earliest Jurassic) psiloceratoid ammonites collected from dark-coloured, clay-rich sediments in a subrosion pipe at Quarry III of the Winterswijk quarry complex is described. The genera Alsatites, Saxoceras and Schlotheimia are determined by comparison to extensive literature on coeval, north German faunas. Taphonomic features are apparent indicating condensation and reworking. Despite this, the portion of the subrosion pipe sediment fill which yielded this material can be dated as middle to late Hettangian.
\end{abstract}

Keywords: Alsatites, Ammonoidea, Lower Jurassic, Saxoceras, Schlotheimia, Winterswijk quarry

\section{Introduction}

The Winterswijkse Steen- en Kalkgroeve, located in the eastern part of the Netherlands near Winterswijk, is well known for its Middle Triassic (Muschelkalk) fossils, notably various reptilian remains such as Nothosaurus, fish, arthropods, bivalves and tracks (0osterink, 1978, 1981; Oosterink \& Poppe, 1979; Demathieu \& Oosterink, 1983; Albers \& Rieppel, 2003; Oosterink et al., 2003).

Only a handful of ammonites have been found in the Winterswijk quarry complex over the past few decades (Boekschoten, 1972; Dertien, 1972; Tjalkens, 1975; 0osterink, 1986), all of Middle Triassic age. Here presented is a small lot of rather poorly preserved ammonite fragments collected from dark clay-rich sediments of earliest Jurassic age.

The Winterswijk quarry complex is situated on the eastern Netherlands plateau, a high on the rim of the Münster Graben in the east and the North Sea Graben in the west (Oosterink et al., 2003). The main deposits exposed at the quarry are light-grey limestones of Middle Triassic (Muschelkalk) age (0osterink, 1986).

The quarry complex comprises four outcrops (Fig. 1), Quarry III being in the centre. Close to the westerly face of Quarry III a subcircular plug of dark, clay-rich sediments about two metres thick and about 30 metres in diameter has recently been exposed (0osterink et al., 2005, 2006). The origin of these clay-rich strata was long unknown until 2004 when it was determined that these were subrosion deposits that had fallen about 10 metres into lower-lying strata (0osterink et al., $2005,2006)$. Subrosion occurs when subsurface rocks become dissolved. Due to leaching of salt domes in the subsurface, a hollow pipe was formed. Eventually, the roof of this pipe collapsed and all overlying material landed in it. There are two salt domes of Röt and Zechstein age in the subsurface that could have caused this subrosion pipe to form. Bentz (1933) and Knapp (1975) determined that, in Germany, an evaporite at the base of the Röt had leached. There is no evidence of leaching of the Zechstein salt anywhere and therefore dissolution of the Röt salt plug is most likely the underlying cause of the Winterswijk subrosion pipe. Oosterink et al. (2006) noted that formation of the subrosion pipe dated back either to the Late Neogene (Miocene or Pliocene) or to a Pleistocene interstadial.

Following discovery of these dark clay-rich sediments, the company (Winterswijksche Steen- en Kalkgroeve B.V.) exploiting the quarry transported and dumped these elsewhere in the 


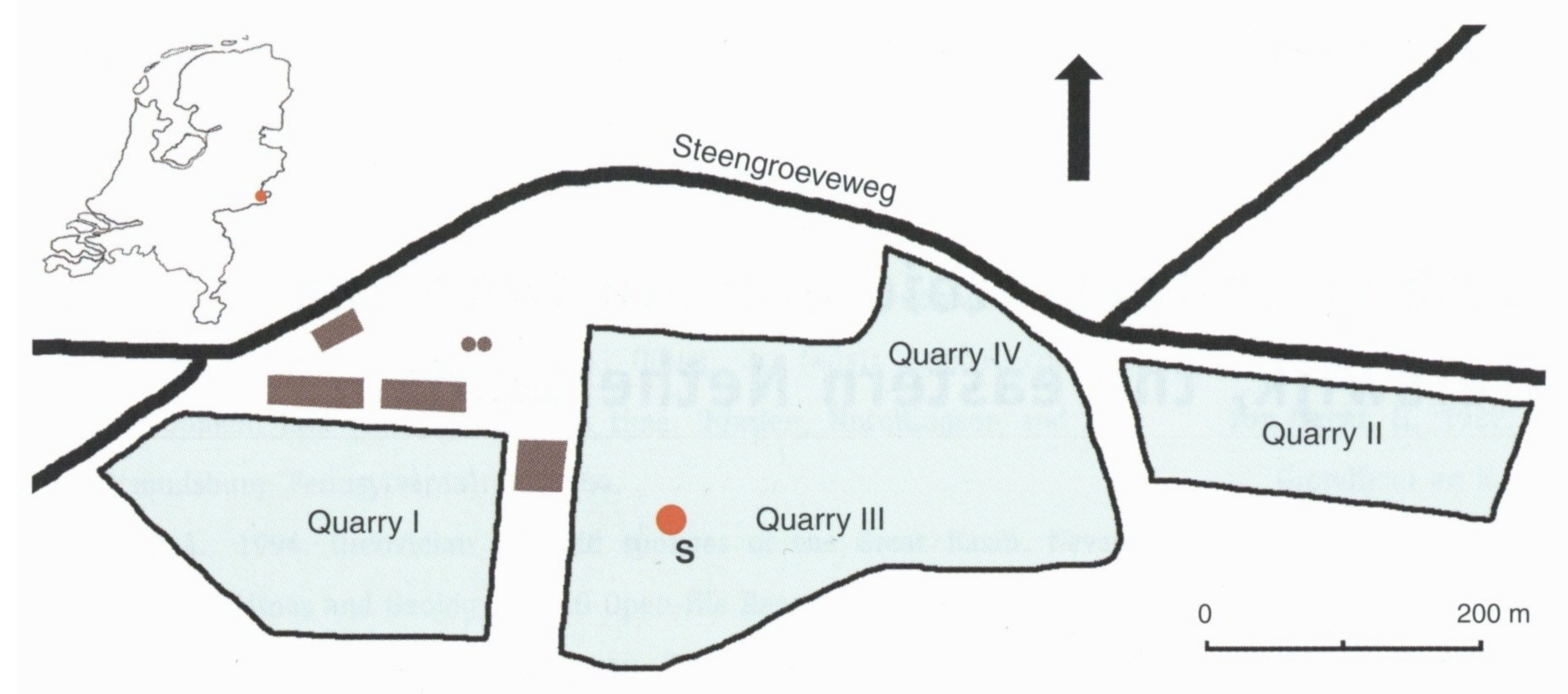

Fig. 1. The Winterswijk quarry complex and the position of the subrosion pipe (S; co-ordinates $\left.51^{\circ} 57^{\prime} 58 \mathrm{~N} / 6^{\circ} 46^{\prime} 47 \mathrm{E}\right)$, indicated by a red dot. quarry, and subsequently covered them with various other material (H.W. Oosterink, pers. comm. November 2006). For this reason, the material is no longer accessible, with the exception of isolated clay-rich sediment occurrences near or at the original location of the subrosion pipe.

In view of the scarcity of Jurassic ammonites at the Winterswijk quarry complex and their biostratigraphical potential, the present fragments have been identified to the generic and/or specific level as best as possible and their zonal provenance determined.

\section{Systematic descriptions}

All dimensions are in millimetres. Abbreviations used are as follows: $\mathrm{Wb}=$ whorl breadth; $\mathrm{Wh}=$ whorl height; $\mathrm{PH}=$ phragmocone; $\mathrm{BC}=$ body chamber; $\mathrm{E}=$ evoluteness = height on symmetric plane / Wh; RGM = Nationaal Natuurhistorisch Museum (Naturalis), Leiden, the Netherlands (formerly Rijksmuseum van Geologie en Mineralogie).

Table 1 lists dimensions of specimens while Fig. 2 illustrates several whorl sections.

Table 1. Measurements (in millimetres).

\begin{tabular}{lccccc}
\hline & PH or BC & Wb & Wh & Wb:Wh & E \\
\hline RGM 542900 & BC & 9.0 & 7.7 & 1.2 & 0.9 \\
RGM 542901 & BC & - & - & - & $\sim 0.9$ \\
RGM 542902 & BC & 9.0 & 10.0 & 0.9 & 0.9 \\
RGM 542903 & BC & 20.5 & $24: 9$ & 0.8 & 0.8 \\
RGM 542904 & BC & - & $5.0-6.0$ & - & - \\
RGM 542905 & BC & 9.1 & 10.6 & 0.9 & 0.9 \\
RGM 542906 & PH & 19.3 & 21.6 & 0.9 & 0.9 \\
\hline
\end{tabular}

Subclass Ammonoidea von Zittel, 1884

Order Ammonitida Hyatt, 1889

Suborder Ammonitina Hyatt, 1889

Superfamily Psiloceratoidea Hyatt, 1867

Family Arietitidae Hyatt, 1867

Subfamily Alsatitinae Spath, 1924

Genus Alsatites Haug, 1894

Type species: Ammonites liasicus d'Orbigny, 1844

\section{Alsatites sp.}

Material

RGM 542900 (Fig. 3a) is a black internal mould found in unlithified clay.

\section{Description}

The whorl section of this evolute body chamber is oval to rounded quadrate (Table 1; Fig. 2). Maximum whorl breadth is at about mid-flank. The venter is faintly fastigate. Ribs are approximated. The weak, rectiradiate, projected ribs weaken from the ventrolateral shoulders onwards but remain visible on the venter. Reaching the venter they curve backwards and seem to cross the venter in a wide convexity. Several unfilled burrows are observed on all sides of the former interface between shell and sediment infilling. The large burrows on the venter and flanks might be of polychaete or sipunculid origin (Rice, 1969; Bromley, 1970), although the burrow on the venter is relatively large.

\section{Discussion}

RGM 542900 can be assigned to Alsatites beyond doubt on account of its strongly evolute, serpenticone shape, the subcircular whorl section and the ribs reaching their maximum height on the flanks. Only A. laqueus (Quenstedt, 1856) and A. liasicus (d'Orbigny, 1844) are possible candidates based on whorl breadth exceeding height and the faintly fastigate venter. However, differences between these two species are too minimal to determine this specimen to species level (Lange, 1941; Donovan, 1952; Schlegelmilch, 1992).

\section{cf. Alsatites sp.}

Material

RGM 542901 (Fig. 3b) is an abraded, black internal mould found in unlithified clay. 


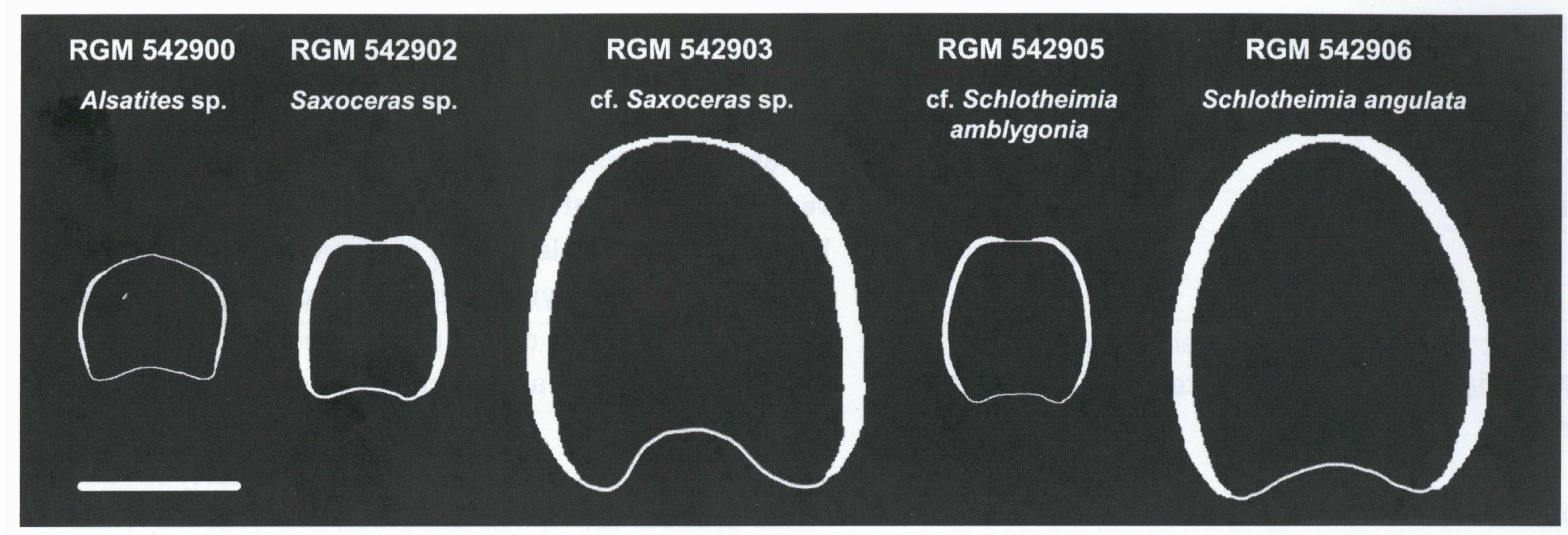

Fig. 2. Whorl sections and relative dimensions of material; scale bar equals $10 \mathrm{~mm}$.

\section{Description}

The whorl section of this evolute body chamber is rounded as far as can be determined. The dorsal side, less heavily worn, shows a fastigate, rounded keel. Burrows are found on all sides of the former interface between shell and sediment infilling. Burrows are mostly filled with grey sediment. Again, a large burrow on the venter and smaller burrows on the flanks might be of polychaete or sipunculid origin.

\section{Discussion}

The overall shape of RGM 542901 is similar to RGM 542900. However, the keel on the venter more pronounced. The only genus in Lange (1941) that resembles this specimen is Alsatites. The rounded fastigate keel also occurs in many specimens of Alsatites, which is why we refer to it as cf. Alsatites sp.

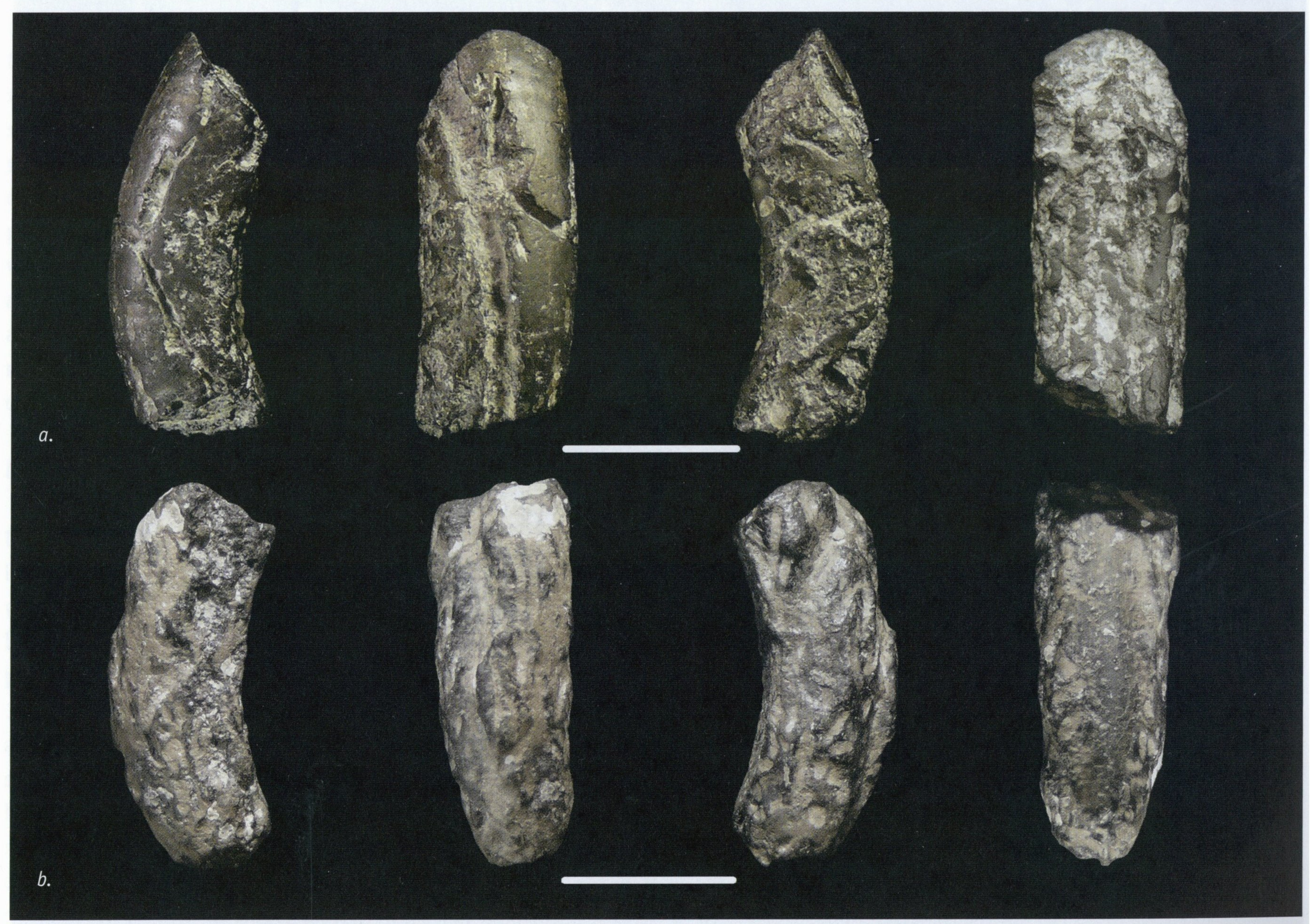

Fig. 3. a. Alsatites sp. (RGM 542900). The left-hand image shows the faint ribbing on the flanks and on the ventrolateral shoulder. The ventral view illustrates very weak ribs crossing ventrolaterally and ventrally; b. cf. Alsatites sp. (RGM 542901). The scale bar represents $10 \mathrm{~mm}$. 
Family Schlotheimiidae Spath, 1923

Genus Saxoceras Lange, 1924

Type species: Psiloceras costatum Lange, 1922

\section{Saxoceras sp.}

\section{Material}

RGM 542902 (Fig. 4a) is a black internal mould found in unlithified clay.

\section{Description}

The whorl section of this initial portion of an evolute body chamber is rectangular with rounded to slightly trapezoidal flanks (Table 1; Fig. 2). Maximum whorl breadth is at inner flank. Venter is flattened and shows a narrow furrow. Ribs are approximated. The sharp, strong, simple, rectiradiate ribs are projected and initiate on the rounded umbilical wall. Curvature of the ribs starts at the beginning of the ventrolateral shoulders. Maximum rib height is reached at the ventrolateral shoulders. Ribs efface rapidly on the venter, merging faintly the opposing ribs. The angle between the opposing ribs on the venter is approximately $90^{\circ}-100^{\circ}$. Only the ultimate suture line is partially visible, mainly on the venter.

Tiny crystalline pyrite crystals are present on the dorsal side. The specimen is devoid of burrows except for a possible portion of a burrow on the distal cross-section of the whorl.

\section{Discussion}

Ribs are too strong in comparison with Schlotheimia amblygonia (Lange, 1924). The ribs in Saxoceras costatum quadratum (Lange, 1941) are too weak and the angle between the opposing ribs on the venter is too large. Saxoceras crassicosta (Brandes, 1912) has gradually effacing ribs on the venter and finally also the angle between the opposing ribs on the venter is too large. Differences between Saxoceras praecursor (Lange, 1924)

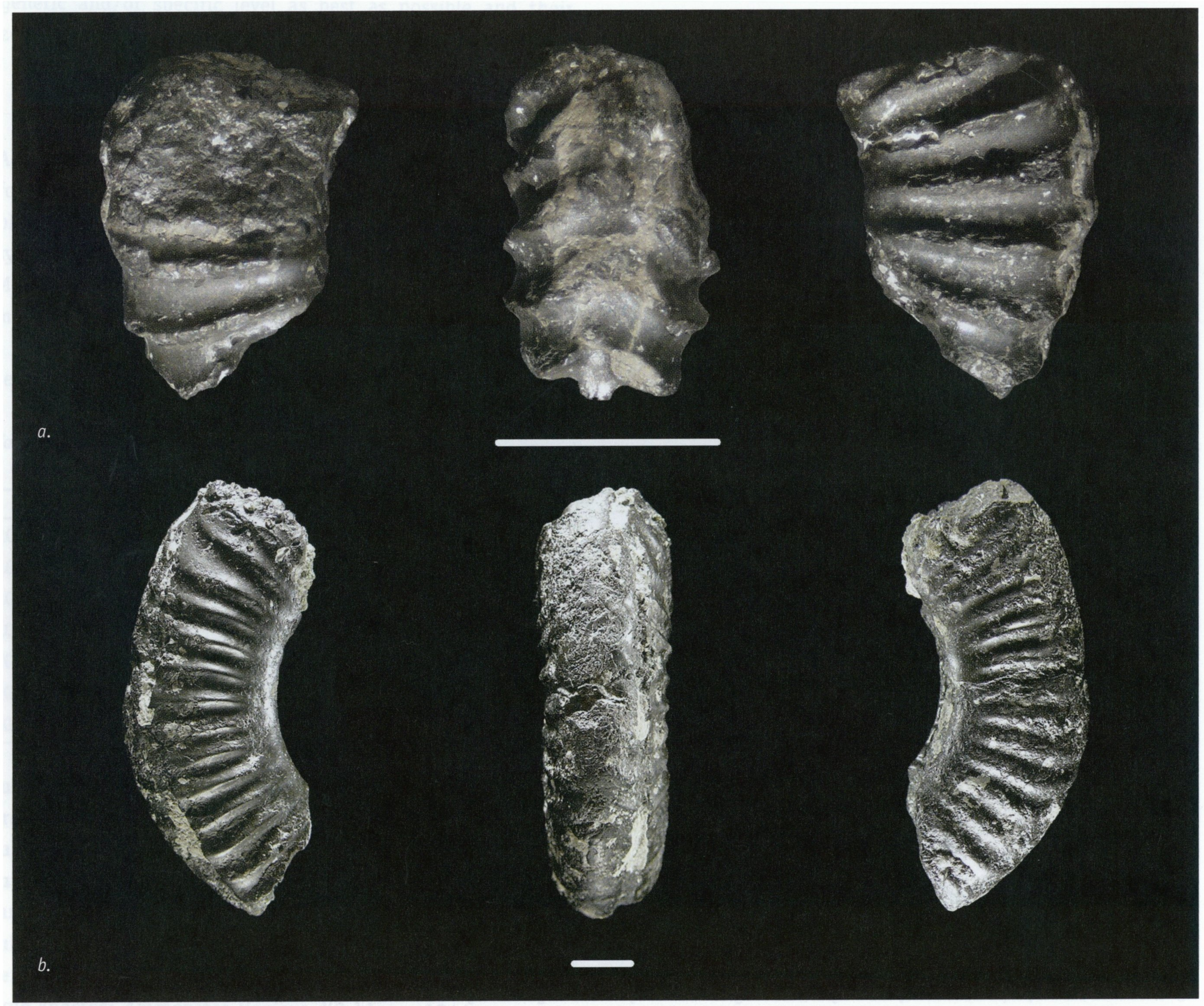

Fig. 4. a. Saxoceras sp. (RGM 542902); b. cf. Saxoceras sp. (RGM 542903); scale bar represents $10 \mathrm{~mm}$. 
and S. schroederi (Lange, 1922) are too small to assign this specimen to one of these confidentially. The specimen does not show (a combination of) characteristics that warrant species identification which is why this specimen is identified as Saxoceras sp.

\section{cf. Saxoceras sp.}

Material

RGM 542903 (Fig. 4b) is a black internal mould which is worn, especially ventrally and ventrolaterally. It was found in dark, clay-rich sediment aggregates.

\section{Description}

The body chamber represents an evolute species with a diameter of at least $80 \mathrm{~mm}$. The whorl section is ellipsoid to oval (Table 1; Fig. 2). Maximum whorl breadth is at mid-flank. The venter is rounded. Ribs are approximated. Simple, rectiradiate, strong to sometimes very slightly falcoid ribs with a flattened top are projected and originate on the outer part of the umbilical rim from which they slowly grow in strength. The sharp, strong, simple, rectiradiate ribs are projected and initiate on the rounded umbilical wall. Curvature of the ribs starts at the beginning of the ventrolateral shoulders. They have their maximum height at mid-flank. The ribs diminish gradually in strength from the ventrolateral shoulders onwards. Ribs very weakly pass the venter. Pyrite crystals are common, especially on the distal cross-section of the whorl. A large fracture, partially filled with grey sediment, is present along the ventrolateral shoulder. Distinct networks of burrows, which are interpreted as phoronid boreholes (compare Voigt, 1972), are mainly found on the venter. Epizoans such as an internal mould and a remineralized bivalve or brachiopod are visible dorsally.

\section{Discussion}

Unfortunately RGM 542903 is damaged ventrally and ventrolaterally. Maximum rib height is reached at the inner flanks which rules out Schlotheimia. As this specimen has a whorl height of about $25 \mathrm{~mm}$, it is considered to be adult. The probable precursor of Saxoceras, the genus Storthoceras Lange, 1941 shows a similar whorl section and ribs which are projected as well. The ribs cross the venter (Lange, 1941). The youngest subgenus of Storthoceras, Megastomoceras Lange, 1941 would have the ribs restricted to the flanks of adult specimens which rules out Megastomoceras because this specimen has ribs connected, although barely visible. This specimen has comparable ribs to Saxoceras, showing the characteristic of ribs like Psiloceras (Hyatt, 1867) in the adult stage. So this specimen is identified as cf. Saxoceras sp.
Genus Schlotheimia Bayle, 1878

Type species: Ammonites angulus Von Schlotheim, 1820

\section{cf. Schlotheimia sp.}

\section{Material}

RGM 542904 (Fig. 5a) is a portion of a grey-coloured internal mould. It was found in dark, clay-rich sediment aggregates.

\section{Description}

The body chamber with slightly rounded flanks is embedded in a grey matrix. The ventral side shows a narrow furrow. Ribs are approximated. Simple, rectiradiate, projected, moderately sharp ribs curve forwards from the mid-flank onwards. Rib height does not change distinctly from the inner part of the flank onwards. The angle between the opposing ribs on the venter is approximately $90^{\circ}$. Neither burrows nor encrustations are encountered.

\section{Discussion}

RGM 542904 is the smallest of all specimens (Wh = $5-6 \mathrm{~mm}$ ) and presumably juvenile. Juvenile specimens of Saxoceras may have ribs crossing the venter (Lange, 1941; Schlegelmilch, 1992), a feature not seen in the present specimen. It shows a narrow furrow, which is usually present in species of Schlotheimia (Lange, 1951). Therefore this specimen is referred to as cf. Schlotheimia sp.

\section{cf. Schlotheimia amblygonia}

\section{Material}

RGM 542905 (Fig. 5b) is part of a black internal mould, in particular worn on the flanks. It was found in dark, clay-rich sediment agglomerations.

\section{Description}

The whorl section of this evolute body chamber is rectangular with rounded flanks (Table 1; Fig. 2). Maximum whorl breadth is near mid-flank height. The venter is flattened and shows a wide furrow. The dorsal side is slightly concave and shows imprints of the previous venter and furrow. Ribs are approximated. The moderately strong, simple, sharp ribs are prorsiradiate and projected and start on outer part of the rounded umbilical wall. Curvature of the ribs starts at the beginning of the ventrolateral shoulders. The maximum rib height is on outer half of the flank as well as on the ventrolateral shoulder. The ribs remain strong and end abruptly on the venter, leaving a smooth siphonal band. The angle between opposite ribs on 

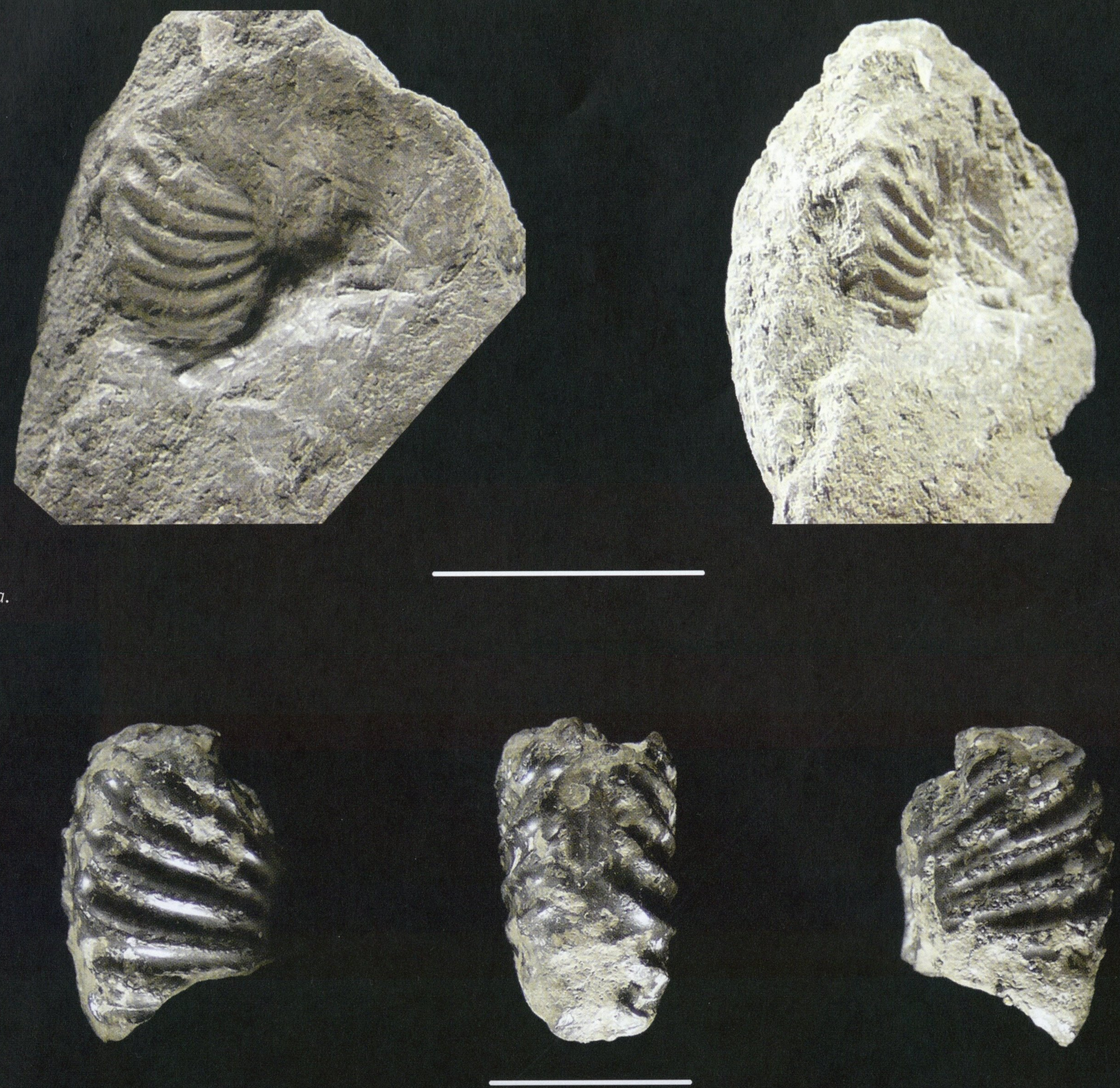

b.
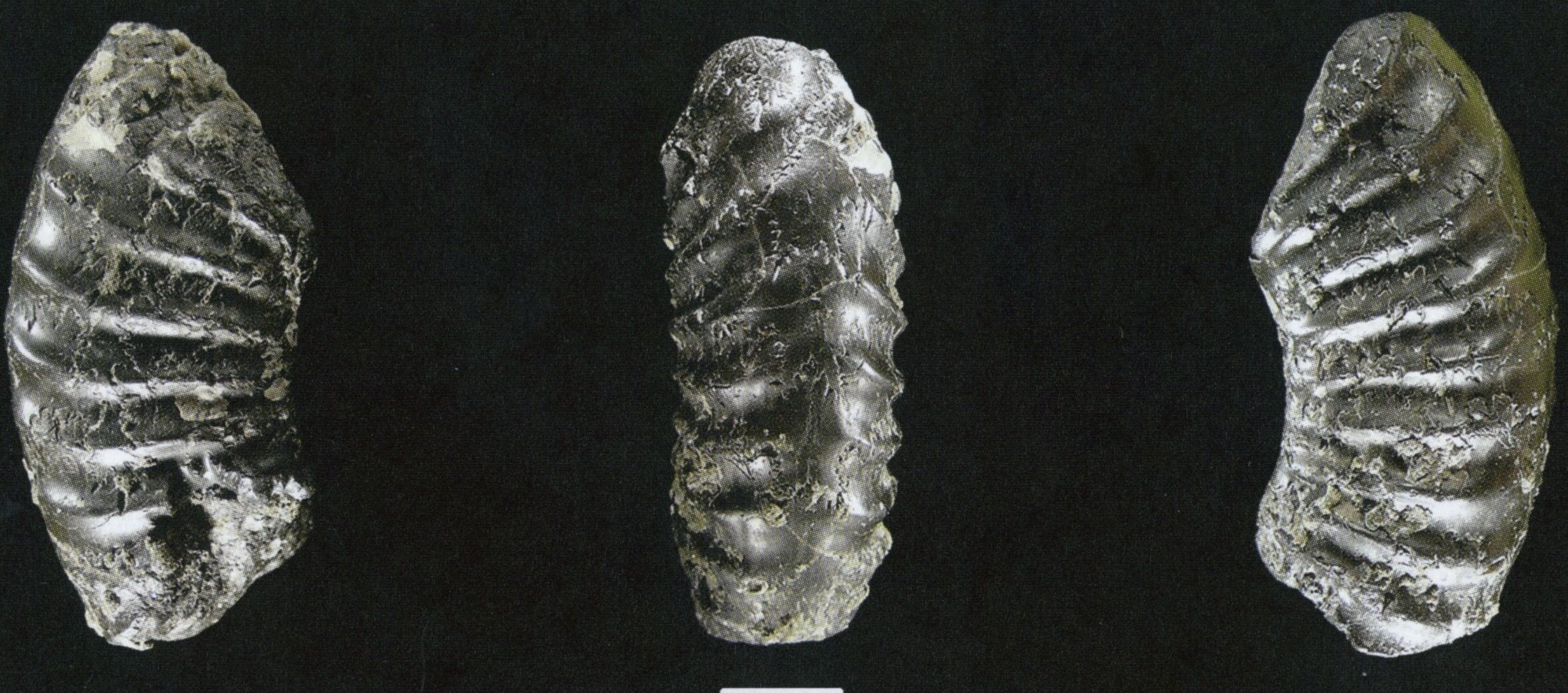

Fig. 5. a. cf. Schlotheimia sp. (RGM 542904); b. cf. Schlotheimia amblygonia (RGM 542905); c. Schlotheimia angulata (RGM 542906); scale bar represents $10 \mathrm{~mm}$. 
the venter is approximately $90^{\circ}$. Small pyrite crystals are especially present on the proximal cross-section of the whorl. No burrows are found.

\section{Discussion}

The rectangular whorl section is distinctive and one of the features commonly seen in Saxoceras (Schlegelmilch, 1992). Saxoceras and Schlotheimia are distinguished by their ontogeny since adult Saxoceras shows psiloceratid-like ribs which have their maximum height on the flanks instead of on the ventrolateral shoulders as in the juvenile stages whereas the ribs of Schlotheimia reach their maximum height on the ventrolateral shoulders in both juvenile and adults stages. Unfortunately, maximum rib height this specimen is not decisive. Lange (1951) illustrated but a single species of Schlotheimia with a similar whorl section, $S$. amblygonia which comprises several subspecies according to Lange (1941). Budwill (1960) considered that this species could be synonymous with Schlotheimia angulata (Von Schlotheim, 1820) but failed to provide evidence for this. Therefore, we regard Schl. amblygonia as a valid species. The genus Saxoceras comprises many rounded-rectangular (sub)species (Lange, 1941) such as $S$. crassicosta, S. schroederi, S. costatum quadratum and S. praecursor. However, RGM 542905 cannot be identified as $S$. crassicosta or $S$. c. quadratum on account of the gradual effacing of the ribs on the ventral side compared to the abrupt ending of RGM 542905, the very blunt angle of opposing ribs being far more than $90^{\circ}$ on the ventral side compared to the near-perpendicular angle of the ribs this specimen and the relatively narrow furrow compared to the wide furrow of this specimen. The ribs in $S$. praecursor and $S$. schroederi are too strong in comparison. Moreover, the latter taxon possesses radial to rursiradiate ribs, in contrast to RGM 542905. The moderately strong, prorsiradiate ribs favour assignment of specimen RGM 542905 to cf. Schlotheimia amblygonia.

\section{Schlotheimia angulata}

Material

\section{Description}

The phragmocone represents an evolute species with an estimated diameter of at least $80 \mathrm{~mm}$. The whorl section is oval (Table 1; Fig. 2). Maximum whorl breadth is at mid-flank. The venter is acutely rounded and shows no furrow. The dorsal side is concave, shows suture lines as well as the imprints of the ribs from the previous inner whorl. Ribs are approximated. Simple, rectiradiate, strong, moderately sharp ribs are projected and originate on the rounded umbilical wall. Curvature of the ribs starts slightly before the beginning of the ventrolateral shoulders. Their maximum height is reached both on the flanks and ventrolaterally. All ribs drastically diminish in strength on the venter and form a chevron with a rounded top. The angle between the opposing ribs on the venter exceeds $90^{\circ}$. Sutures show two distinct lateral saddles and a lateral lobe (Fig. 6). Pyrite crystals are present mainly on the proximal cross-section of the whorl. Few burrows of conjectural origin (Henderson \& McNamara, 1985) are present; most of them are positioned near or on the venter and are interpreted to have originated from a possible polychaete or sipunculid. Also, a network of burrows belonging to a possible phoronid is visible on the ventrolateral shoulder. An epizoan, represented by its convex dorsal side filled with grey sediment, is present on the distal cross-section.

\section{Discussion}

The oval whorl section of RGM 542906 closely resembles that of Schlotheimia angulata. This specimen is remarkably large compared to other specimens of Schl. angulata which generally have a diameter smaller than $50 \mathrm{~mm}$ (Lange, 1951; Blind, 1958, 1963; Budwill, 1960). On the other hand, the suture lines resemble those of Schl. angulata in detail and thus rule out Schl. germanica (Lange, 1924) which has a more complex suture. Strong ribs end abruptly on the ventrolateral shoulders at an angle of more than $90^{\circ}$ which is also comparable to Schl. angulata as well, which is why we favour assignment to that species.

RGM 542906 (Fig. 5c) is a portion of a black internal mould found in unlithified clay.

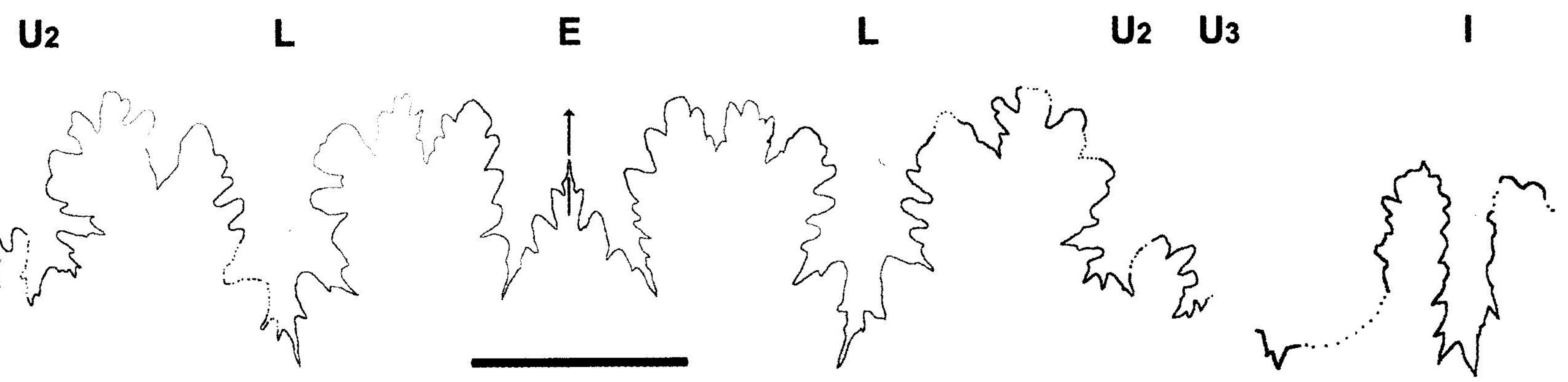

Fig. 6. Suture line of Schl. angulata (RGM 542906) at Wh $=22 \mathrm{~mm}$; scale bar equals $10 \mathrm{~mm}$. 


\section{Discussion}

\section{Palaeogeography and literature}

During the Early Jurassic, the Winterswijk area was flooded by an epicontinental shallow sea, which extended over large portions of today's North Sea, the Netherlands, Denmark and Germany (Dercourt et al., 2000). The Rhenish and LondonBrabant massifs as main landmasses to the south and structural highs in present-day Scandinavia and Great Britain to the north and west, respectively, acted as the continental boundaries.

The ammonites described have been compared with their north German contemporaries because these are found mainly only about $130-140 \mathrm{~km}$ east of Winterswijk near the Herforder Mulde and are supposed to be fairly similar because of direct palaeogeographical connections. Moreover, most of the north German ammonites also have been found in dark, clay-rich sediments (Lange, 1924) representing the same marine conditions (Herngreen et al., 2005a, b). The north German ammonites have been found in great numbers and described and illustrated in considerable detail (Lange, 1941, 1951).

\section{Taphonomy and stratigraphy}

At least three different preservational types can be distinguished. RGM 542900 and 522901 are black, heavily burrowed and show no pyrite crystals. This extensive burrowing suggests condensation. Markedly different are RGM 542902, 542903, 542905 and 542906: black, showing few burrows, bearing pyrite crystals and sometimes showing encrustations dorsally suggesting reworking. RGM 542903 and 524906 have grey sediment in several depressions, implying that they may have been temporarily embedded in grey sediment after having been reworked. The third preservational type is represented by the grey specimen of RGM 542904 which has none of the above features.

Reworking is apparent from several worn species. Also, the presence of lithified grey sediment in depressions in relation to the sediment in which the specimens were found frequently (unlithified clay) suggest reworking. Low sedimentation rates, often related to clay deposition, also would have enhanced the process of reworking.
All specimens are parts of ammonites and represent less than $120^{\circ}$ of a whorl. Mechanical damage after lithification would be the likely cause.

Based on our findings, body chambers (6) are preferred for preservation over phragmocones (1) because they are relatively quickly filled with sediment compared to phargmocones (Henderson \& McNamara, 1985). Complete and comparable sedimentary infill of all chambers occurs in RGM 542906. Sediment infill of chambers could be either through the siphuncle or through endolith borings in the shell of which the former would be of minor importance (Henderson \& McNamara, 1985). Because of complete infilling, this species would have remained a considerable time at the sedimentwater interface while endoliths might have sped up the process of infilling. The low sedimentation rate, as suggested by the clayey sediment, might be responsible for it.

Lowermost Jurassic (bio)stratigraphy for northwest and central Europe is summarised in Table 2, while Table 3 shows the present ammonite material with its inferred stratigraphic position. It appears that they can be placed either in ammonite

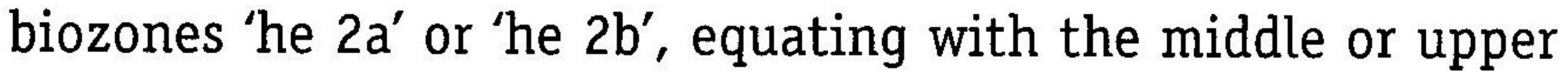
Hettangian, respectively. Saxoceras is considered to be the precursor of Schlotheimia (Lange, 1941, 1951; Blind, 1966; Guex, 1995), the evolutionary transition corresponding with the middle to upper Hettangian boundary. The present ammonites might cover biozones he $2 \mathrm{a}$ and he $2 \mathrm{~b}$ wholly or in part.

Boreholes in close proximity of the Winterswijk quarry complex have penetrated Hettangian sediments as well (Gerth, 1955; Herngreen et al., 2000). Boreholes 'Ratum' and 'E', both within three kilometres distance from the quarry, have yielded the index species Schlotheimia angulata (see Gerth, 1955). The middle and upper Hettangian would reach thicknesses of $\geqslant 33 \mathrm{~m}$ and $\leqslant 15 \mathrm{~m}$, respectively, although Gerth (1955) estimated a total thickness of $60 \mathrm{~m}$. Herngreen \& De Boer (1974) found the 'Schlotheimia Schichten' to be about $50 \mathrm{~m}$ in thickness based on palynological data for borehole E. Boreholes 'Mennink-4 41E-315' and 'Ratum 41E-129', both less than four kilometres distance from the quarry, penetrated Hettangian sediments as shown on foraminifer, ostracod, dinoflagellate and sporomorph evidence (Herngreen et al., 2000). On a larger geographic scale, Lower Jurassic sediments are relatively common, occurring in a synclinal structure in the shallow underground

Table 2. European lowermost Jurassic and uppermost Triassic stratigraphy based on Schlegelmilch (1992); absolute datings from www.stratigraphy.org.

\begin{tabular}{|c|c|c|c|c|c|c|}
\hline System & Series & Stage & Absolute ages (Ma) & German stratigraphy & Biostratigraphy & Ammonite zones \\
\hline \multirow[t]{4}{*}{ Jurassic } & \multirow[t]{4}{*}{ lower Liassic } & Sinemurian & \multirow{3}{*}{$196 \pm 1.0$} & $\alpha 3$ & si $1 \mathrm{a}$ & Arietites bucklandi \\
\hline & & \multirow{3}{*}{ Hettangian } & & $\alpha 2$ & he $2 b$ & Schlotheimia angulata \\
\hline & & & & $\&$ & he $2 \mathrm{a}$ & Alsatites liasicus \\
\hline & & & \multirow{2}{*}{$199,6 \pm 0.6$} & $\alpha 1$ & he 1 & Psiloceras planorbis \\
\hline Triassic & Keuper & Rhaetian & & & & \\
\hline
\end{tabular}


Table 3. Inferred stratigraphy provenance of ammonite material; question mark corresponds to the use of 'cf.' prefix in assignments.

\begin{tabular}{lll}
\hline & Ascription & Biozone \\
\hline RGM 542900 & Alsatites sp. & uppermost? he 2a \\
RGM 542901 & cf. Alsatites sp. & he 2a? \\
RGM 542902 & Saxoceras sp. & he 2a \\
RGM 542903 & cf. Saxoceras sp. & he 2a? \\
RGM 542904 & cf. Schlotheimia sp. & he 2b? \\
RGM 542905 & cf. Schlotheimia amblygonia & lowermost he 2b? \\
RGM 542906 & Schlotheimia angulata & he 2b \\
\hline
\end{tabular}

to the north-east-east of Winterswijk near the German border (see Herngreen et al., 2000). The Winterswijk quarry complex is situated a few hundreds of metres to the south of the southerly boundary of the syncline. So, Hettangian strata of the Aalburg Formation (Herngreen et al., 2000) with their fossil content are common in the direct vicinity of Winterswijk.

The fact that only two metres were present in the subrosion pipe at the Winterswijk quarry complex might indicate that it represents only a part of the Hettangian compared with the thicknesses of two nearby boreholes, although local differences might occur. Oosterink et al. (2005) hypothesised that there must have been many metres more of these dark clay-rich sediments at the time the pipe collapsed but Hettangian thicknesses like mentioned before are not expected. The result that these ammonites originated from different layers concurs with the results of Gerth (1955), who documented the Hettangian 'Schlotheimia Schichten' to consist of dark clay and grey calcareous layers based on data for boreholes $E$ and Ratum. The mentioned aspects imply that the specimens are likely to have originated from a part of the middle to late Hettangian rather than covering the whole range of these substages.

It appears to date that only middle and late Hettangian ammonites have been recovered and not any early Hettangian or even Rhaetian species. This implies that Rhaetian and lower Hettangian sediments might not have been present when the subrosion pipe filled during collapse. Oosterink et al. (2005, 2006) noted that few Rhaetian sediments might have been present based on the occurrence of red spots in the lower part of the dark-coloured, clay-rich sediments which yielded dark shale. This is based on the work of Gerth (1955), who assumed that these red spots might be of Rhaetian age. Another counterargument is that the dark Rhaetian sediments at Quarry IV do not contain these red spots, but instead show a few tiny light-brown/red layers (H.W. Oosterink, pers. comm. April 2007). Also, Herngreen et al. (2005a, b) documented that the black Rhaetian strata at Quarry IV rapidly pinch out in a southerly direction. On the other hand, disarticulated fish remains, similar bivalves and possible parts of a pyrite layer are present in both the lower part of the dark-coloured, clay-rich sediments in the subrosion pipe and in the Rhaetian sediments of Quarry IV. So, the existence of Rhaetian sediments still has to be validated. Currently, there are no indications for lower Hettangian sediments to be present in the subrosion pipe.

In conclusion, a hiatus covering more than $40 \mathrm{Ma}$ is present between the Muschelkalk (Anisian, Bithynian) strata (Herngreen et al., 2005b) and the dark clay-rich sediments, indicated by the sudden transition from light grey to very dark-grey/black (0osterink et al. 2006, fig. 5).

Lissenberg (1989) documented that a preliminary age assessment to these dark clay-rich sediments, as based on ostracods, foraminifers and holothurians, indicated the Hettangian/Sinemurian boundary. He also stated that more material was needed to obtain a better-constrained dating. Herngreen (1989) concluded that the dark clay-rich sediments presumably were of late Hettangian age as based on sporomorph evidence.

Our present results corroborate results of Lissenberg (1989) and Herngreen (1989) suggesting a middle to late Hettangian age for a part of the dark, clay-rich sediments from the subrosion pipe.

\section{Acknowledgements}

We wish to thank Herman Akkerman, Paul Albers, Heiner Becker, Rob van den Berkmortel, René Fraaije, Jean Guex, Waldemar Herngreen, Betsie Klompmaker, Edo Klompmaker, Henk Oosterink, Rudolf Schlegelmilch, Jobst Wendt, Albert van de Werfhorst, Wouter Wildenberg and the university librarians at Tübingen for assistance in various ways. Also, Philip Hoedemaeker and John Jagt are thanked for improving the article.

\section{References}

Albers, P.C.H. \& Rieppel, O., 2003. A new species of the sauropterygian genus Nothosaurus from the Lower Muschelkalk of Winterswijk, the Netherlands. Journal of Paleontology 77: 738-744.

Bayle, $\tilde{E}_{.}, 1878$. Fossiles principaux des terrains de la France. Explication de la Carte Géologique de la France 4 (1), Atlas, pls 80-158. Paris (Imprimerie nationale).

Bentz, A., 1933. Erläuterungen zu Blatt Oeding 4006. Geologische Karte von Preußen und benachbarten Ländern $1: 25000$ (Berlin): 63 pp.

Blind, W., 1958. Die Ammoniten des Lias alpha und ihre Entwicklung. Tübinger Dissertation.

Blind, W., 1963. Die Ammoniten des Lias alpha aus Schwaben, vom Fonsjoch und Breitenberg (Alpen) und ihre Entwicklung. Palaeontographica A 121: 38-131.

Blind, W., 1966. Über die verwantschaftlichen Beziehungen von Schlotheimia zu Storthoceras. Neues Jahrbuch für Geologie und Paläontologie, Abhandlungen 125: $125-135$.

Boekschoten, G.J., 1972. Über einige Molluskenfunde im Wellenkalk von Winterswijk (Niederlande). Geologie en Mijnbouw 51: 574-575. 
Brandes, T., 1912. Liasaufschlüsse bei Bünde in Westfalen. Zeitschrift der deutschen geologischen Gesellschaft 64: 1-125.

Bromley, R.G., 1970. Borings as trace fossils and Entobia cretacea Portlock, as an example. In: Crimes, T.P. \& Harper, J.C. (eds): Trace fossils. Seel House Press (Liverpool): 49-90.

Budwill, H., 1960. Die Variabilität einger Arten von Schlotheimia (Ammonoidea) Norddeutschlands. Tübinger Dissertation.

Demathieu, G. \& Oosterink, H.W., 1983. Die Wirbeltier-Ichnofauna aus dem Unteren Muschelkalk von Winterswijk (Die Reptilienfährten aus der Mitteltrias der Niederlande). Staringia 7: 1-52.

Dercourt, J., Gaetani, M., Vrielynck, B., Barrier, E., Biju-Duval, B., Brunet, M.F., Cadet, J.P., Crasquin, S. \& Sandulescu, M., 2000. Peri-Tethys Paleogeographical Atlas, 24 Maps and explanatory notes. CCGM/CGMW (Paris): $269 \mathrm{pp}$

Dertien, B.K., 1972. Een ammoniet uit de Winterswijkse Muschelkalk. Grondboor en Hamer 26: 132.

Donovan, D.T., 1952. The ammonites of the Blue Lias of the Bristol District. Part I. Psiloceratidae and Schlotheimidae. Annals and Magazine of Natural History (12) 5: 629-655.

d'Orbigny, A., 1842 - 1849. Paléontologie française; terrains jurassiques. I: céphalopodes. Masson (Paris): 642 pp.

Gerth, H., 1955. Die Fossilführung des Jura in den Bohrungen der 'Rijksopsporing van Delfstoffen' bei Winterswijk und ihre stratigraphische Bedeutung. Mededelingen van de Geologische Stichting, Nieuwe Serie 9: 45-54.

Guex, J., 1995. Ammonites hettangiennes de la Gabbs Valley Range (Nevada, USA). Mémoires de Géologie, Lausanne, 27: 1-131.

Haug, $\tilde{E}_{.}, 1894$. Les Ammonites du Permien et du Trias. Remarques sur leur classification. Bulletin de la Société géologique de France 3 (22): 385-412.

Henderson, R.A. \& McNamara, K.J., 1985. Taphonomy and ichnology of cephalopod shells in a Maastrichtian chalk from Western Australia. Lethaia 18: $305-322$.

Herngreen, G.F.W., 1989. Resultaat van het palynologisch onderzoek van een kleimonster uit Steengroeve III te Winterswijk. Rijks Geologische Dienst, Paleontologie Mesozoicum, (Palynologie), Intern Rapport 2217: 2 pp.

Herngreen, G.F.W. \& De Boer, K.F., 1974. Palynology of Rhaetian, Liassic and Dogger strata in the eastern Netherlands. Geologie en Mijnbouw 53: 343-368.

Herngreen, G.F.W., Van den Bosch, M. \& Lissenberg, T., 2000. Nieuwe inzichten in de stratigrafische ontwikkeling van Jura, Krijt en Onder-Tertiair in de Achterhoek. Grondboor en Hamer 54: 70-92.

Herngreen, G.F.W., Van Konijnenburg - van Cittert, J.H.A. \& Oosterink, H.W., 2005a. New geological data (Middle Triassic, Rhaetian-Liassic and Oligocene) of the Winterswijk quarry, the eastern Netherlands. Netherlands Journal of Geosciences 84: 409-413.

Herngreen, G.F.W., Van Konijnenburg - van Cittert, J.H.A., Oosterink, H.W. \& Van der Ham, R.W.J.M., 2005b. Nieuwe geologische, palynologische en paleobotanische gegevens (Muschelkalk, Rhaetien-Lias en Oligoceen) uit de steengroeven van Winterswijk. Grondboor en Hamer 59: 84-97.

Hyatt, A., 1867. The fossil cephalopods of the Museum of Comparative Zoology. Bulletin of the Museum of Comparative Zoology, Harvard University, 1: 71-102.

Hyatt, A., 1889. Genesis of the Arietidae. Smithsonian Contributions to Knowledge 26 (673): $x i+239 \mathrm{pp}$.

Knapp, G., 1975. Trias. In: Braun, F. J. \& Thiermann, A. (ed.): Erläuterungen zu Blatt C 4306 Recklinghausen, Geologische Karte Nordrhein-Westfalen $1: 100$ 000: 40-52.
Lange, W., 1922. Über den untersten Lias der Herforder Mulde (Psilonoten- und Angulatenschichten). Jahrbuch der preußischen geologischen Landesanstalt 42: 461-490.

Lange, W., 1924. Über die Psilonotenstufe und die Ammonitenfauna des untersten Lias Norddeutschlands. Jahrbuch der Preußischen Geologischen Landesanstalt 44: 177-207.

Lange, W., 1941. Die Ammonitenfauna der Psiloceras-Stufe Norddeutschlands. Palaeontographica A 93: 1-216.

Lange, W., 1951. Die Schlotheimiinae aus dem Lias Alpha Norddeutschlands. Palaeontographica A 100: 1-128.

Lissenberg, T., 1989. Mikropaleontologisch onderzoek aan een kleimonster uit de steengroeve te Winterswijk. Rijks Geologische Dienst, Paleontologie Mesozoicum (Foraminiferen en 0stracoden), Intern Rapport 497: 5 pp.

Oosterink, H.W., 1978. Arthropoda (Geleedpotigen) uit de Onder-Muschelkalk van Winterswijk. Grondboor en Hamer 32: 3-9.

Oosterink, H.W., 1981. De lamellibranchiaten uit de Winterswijkse OnderMuschelkalk. Grondboor en Hamer 35: 53-60.

Oosterink, H.W., 1986. Winterswijk, Geologie Deel II. De Triasperiode (geologie, mineralen en fossielen). Wetenschappelijke Mededelingen van de Koninklijke Nederlandse Natuurhistorische Vereniging 178: 1-120.

Oosterink, H.W. \& Poppe, W., 1979. Vissen en visresten uit de Onder-Muschelkalk van Winterswijk. Grondboor en Hamer 33: 95-112.

Oosterink, H., Berkelder, W., De Jong, C., Lankamp, J. \& Winkelhorst, H., 2003. Sauriërs uit de Onder-Muschelkalk van Winterswijk. Staringia 11: 1-146.

Oosterink, H., Simon, Th. \& Winkelhorst, H., 2005. Een subrosieverschijnsel in de Muschelkalkgroeve van Winterswijk. Grondboor en Hamer 59: 78-83.

Oosterink, H.W., Simon, Th., Hagdorn, H. \& Winkelhorst, H., 2006. A subrosion pipe fill in the Lower Muschelkalk, Winterswijk Quarry, eastern Netherlands. Netherlands Journal of Geosciences 85: 293-297.

Quenstedt, F.A., 1856 - 1858. Der Jura. Laupp (Tübingen): vi + 842 pp.

Rice, M.E., 1969. Possible boring structures of sipunculids. American Zoologist 9: 803-812.

Schlegelmilch, $R ., 1992$. Die Ammoniten des süddeutschen Lias. Gustav Fischer Verlag (Stuttgart-Jena-New York): $241 \mathrm{pp}$.

Spath, L.F., 1923. The ammonites of the shales-with-beef. Quarterly Journal of the Geological Society of London 79: 66-88.

Spath, L.F., 1924. The Ammonites of the Blue Lias. Proceedings of the Geologists' Association 35: 1-186.

Tjalkens, J., 1975. Nogmaals een 'Winterswijkse' ammoniet. Grondboor en Hamer 29: 192.

Voigt, E., 1972. Über Talpina ramosa v. Hagenow 1840, ein wahrscheinlich zu den Phoronoidea gehöriger Bohrorganismus aus der Oberen Kreide. Nachrichten der Akademie der Wissenschaften zu Göttingen, II. MathematischPhysikalische Klasse 7: 93-126.

Von Schlotheim, E.F., 1820. Die Petrefaktenkunde auf ihrem jetzigen Standpunkt durch die Beschreibung seiner Sammlung versteinerter und fossiler Überreste des Thier- und Pflanzenreichs der Vorwelt erläutert. Becker (Gotha): 499 pp.

Von Zittel, K.A., 1884. Handbuch der Paläontologie, 1(2)3. Cephalopoda. R. Oldenburg (München/Leipzig): 329-522. 